\title{
THE EFFECT OF FINANCIAL PERFORMANCE AND GROWTH OPPORTUNITY ON INVESTMENT DECISIONS IN FOOD AND BEVERAGE COMPANIES IN INDONESIA STOCK EXCHANGE
}

\author{
Yulia Tri Kusumawati* \\ Fakultas Ekonomi, Hukum, Politik dan Psikologi \\ Universitas Muhammadiyah Kalimantan Timur, Kaltim, Indonesia \\ *Corresponding author: ytk716@umkt.ac.id
}

\begin{abstract}
This study aims to analyze the effect of Liquidity, Debt to Asset, Asset Turnover, and Growth on Investment Decisions in Food and Beverage Companies in the Indonesia Stock Exchange. The sample in this study are six (6) Food and Beverage group companies listed on the Indonesia Stock Exchange in 2013-2017. Sample selection was done by using purposive sampling method. This is a causal research with quantitative methods. Data analysis method in this study used multiple regression analysis, classic assumption test, and hypothesis testing (t-test) using SPSS 22. The results show that partially, Liquidity and Growth Opportunity have a negative and significant effect on Investment Decisions, while Debt Asset and Asset Turnover has a negative and insignificant effect on Investment Decisions. Simultaneously, the Liquidity variable, Debt to Asset, Asset Turnover, and Growth have no significant effect on Investment Decisions.
\end{abstract}

Keywords: Asset Turnover, Debt to Asset, Growth, Investment Decisions, Liquidity.

Received June $2019 \quad$ Revision January $2^{\text {nd }} 2020 \quad$ Accepted for Publication January $10^{\text {th }} 2020$

\section{INTRODUCTION}

Every company always wants its business to grow. Development will occur if there is a management capability within the company that sets policies in a planning and can utilize funds to maximize company values. The ability to generate maximum profits in a company is very important because basically the parties involved, for example investors and creditors measure the success of the company based on the ability based on visible performance of management in generating profits in the future. There are various ways that companies can do to meet their capital needs, such as by borrowing funds from creditors or making investments. Investments can also be in the form of profitable projects or investment in share ownership by issuing new shares.

But, in making this investment decision, investors must be careful. Investors must ensure that their capital deposit can get the maximum return. This can be analyzed based on certain company conditions. Companies with good financial condition and performance will attract more investors to invest.

The investment decision can be said as a first step for the company to determine the amount of assets that must be owned to obtain profits in the future. Thus managers need to consider what factors can influence investment decisions in order to choose a good investment 
opportunity for the company. The relationship between investment decisions and funding decisions is also influenced by liquidity. Hidayat (2010) stated that Investment decisions made by companies are influenced by the company's ability to generate cash that can meet long-term and short-term needs, or what is called company liquidity.

Hidayat (2010) also stated that investment opportunity is the value of the company, the amount of which depends on the expenses determined by management in the future, in this case investment choices that are expected to generate greater profits. Investment must be considered carefully because it deals with the risks in the future. Therefore, investment decision making must also consider the company's Debt to Total Assets factor. Hartono and Wahyuni (2017) in their research on Property and Real Estate companies stated that Debt to Total Assets significantly influenced investment decisions.

The condition of company assets is also the basis for investors in making investment decisions. The condition of a company's assets is usually measured by the financial ratio of Total Asset Turnover. Total Asset Turnover (TATO) measures the level of effectiveness of the company in using the company's operating assets to generate sales in order to obtain revenue (Prihadi, 2012). Total Asset Turnover (hereinafter referred to as TAT) also has functions to measure a company's ability to use its total assets in generating net sales (Ang, 1997). The greater the TAT shows the more efficient use of all company activities to support sales activities. This shows that the company's performance is getting better so that it can increase company profits.

Another factor that is important in influencing investment decisions is Growth Opportunity. Companies with high Growth Opportunity tend to invest to support its growth. In accordance with Myers (1977) about the concept of investment opportunity set (IOS). The company will have growth opportunities if the currently selected investment can provide benefits in the future. Company growth is a sign that the company has favorable aspects and they expect a better rate of return from investment (Sriwardany, 2007). Increasing competition and the need for funds to develop a business make the company must really understand the factors that can attract investors to invest. If the company ignores this, then the investor will turn to other companies and the company may have great difficulty in getting capital to be able to grow.

\section{Purpose}

The general purpose of this study is to develop previous research related to the relationship between Liquidity to Equity Ratio, Debt to Asset, Turnover Asset, Growth Opportunity, and Investment Decisions. To achieve these general objectives, there are several specific objectives in this study:

1. To test the effect of Liquidity to Equity Ratio, Debt to Asset, Turnover Asset, and Growth Opportunity partially on Investment Decisions

2. T test the effect of Liquidity to Equity Ratio, Debt to Asset, Turnover Asset, and Growth Opportunity on Investment Decisions simultaneously

\section{Urgency}

Every company must have a goal to develop and expand its business. But to carry out the development, it needs a large amount of capital. The increasingly fierce competition makes companies competing to attract investors so they can invest in their companies. Therefore, determining the right strategy must be carried out. One is to pay attention to the performance and financial condition of the company, by analyzing the financial ratios. From the company side, if the company already knows the good and bad conditions in their internal, it will be easier to carry out improvement strategies. While in terms of investors, the results of the research will be used as a basis for consideration in making investment decisions in a company.

This research was conducted using Food and Beverage companies listed in the Indonesia 
Stock Exchange in 2014-2016. The selection of this company as the object of research is according to previous researchers. Saragih (2008) said food and beverage industry companies listed on the IDX will survive and are most resistant to crisis compared to other sectors because whether in a crisis condition or not, food and beverage products are still needed by their customers.

\section{LITERATURE REVIEW} Investment decision

Investment decision is an important factor in the financial function where the value of the company is solely determined by investment decision because in order to achieve the company's goals, that is maximizing shareholder's assets will only be generated through corporate investment activities (Hidayat, 2010). Investment decisions for shareholders are very important because investment is used as an indicator of the existence of a company that if the company does not have new investment, then the company does not have a positive prospect (Anjani, 2012).

According to Hanafi (2004), in the analysis of investment decisions, there are several steps to be taken:

a. Estimating the cash flow from the investment

b. Calculates the weighted average cost of capital

c. Evaluate the investments with investment criteria such as pay back period, NPV, and IRR.

d. Make a decision, whether the investment is accepted or not.

\section{Liquidity Ratio}

Liquidity Ratio is the company's ability to meet its short-term financial obligations and help the company in working capital management (Sartono, 2010). Liquid companies will be trusted by investors because they believe the company can pay off all obligations on time, on the other hand, these companies will generally tend to use internal funds rather than external funds in the form of debt.

\section{Total Asset Turnover (TATO)}

According to Darsono and Ashari (2005), the ability of a company to use its assets to generate sales is described in this ratio. The higher the Total Assets of TurnOver, the higher the company's efficiency in the use of its assets, thus, limiting the purchase of new activities.

According to Halim (2007), Total Asset Trunover is a ratio of activities used to measure how much the effectiveness of a company in utilizing its assets.

\section{Debt to Asset Ratio}

Kasmir (2010) stated that the Debt to Asset Ratio is a debt ratio that is used to measure the ratio between total debt to total assets. In other words, how much the company's assets are financed by debt or how much the company's debt affects the management of assets.

Meanwhile, according to Syamsuddin (2009), this ratio measures how much assets are financed by creditors. The higher the debt ratio, the greater the amount of loan capital used in generating profits for the company. Harahap (2010) stated the same thing, that this ratio shows the extent to which debt can be covered by assets, the larger the assets, the ratio is safer (solvable).

\section{Growth Opportunity}

Growth is how far the company places itself in the overall economic system for the same industry. Machfoedz (2007) said companies with high Growth Opportunities tend to invest to support their growth. Growth is included in this study as one of the variables that can affect a company because the higher the company is to make a profit, the greater the return on investment expected by investors.

Febriyani and Mindarti (2010) growth opportunities show the growth in market value of company assets compared to the book value of assets owned by the company. A growing company has an asset market value that is greater than the book value due to an increase in the company's stock 
price in the stock market.

\section{DEVELOPMENT OF HYPOTHESIS}

One of the bases used in this study is the result of previous studies. Previous studies aimed to provide an overview of the problems which is discussed from various theories, methods, and approaches. Previous research will also be a benchmark for researchers to make new findings that will be a differentiator between this research and previous research.

The research conducted by Anjani (2012) with the title "Analysis of Factors That Influence Investment Decisions in Food and Beverage Companies in the Indonesia Stock Exchange". The results of the study indicate that liquidity and investment opportunities do not have a significant influence on investment decisions; and Profitability (Return On Investment) has a significant positive effect on investment decisions; Debt ratio does not have a significant effect on investment decisions. in a positive direction; The company's growth opportunities do not have a significant influence on investment decisions; Corporate growth opportunities can moderate the effect of debt on investment development, but with a negative direction. While Hartono and Wahyuni (2017), examined the effect of the profitability variable (Return On Investment), liquidity variable (Current Ratio), solvency variable (Debt to Asset), activity variable (Total Asset Turn Over) on Investment Decisions in Property and Real Estate Companies . Based on the results of these studies, partially, that Return On Investment (ROI), Current Ratio (CR), Debt to Asset (DTA), and Total Asset Turn Over (TATO) have positive and significant effect on investment decisions.

Based on the literature and the results of previous studies, the hypotheses of this study are as follows:

$\mathbf{H}_{\mathbf{1}}$ : Liquidity to equity ratio significantly influences investment decisions.

$\mathbf{H}_{2}$ : Debt to Asset Ratio (DAR) has a significant effect on Investment Decisions.

$\mathbf{H}_{3}$ : Total Asset Turnover (TATO) has a significant effect on Investment Decisions.

Another study related to Growth Opportunity was conducted by Sandiar (2012) with the title "Growth Opportunity in moderating the influence of Leverage and Debt Maturity on Investment Decisions" in companies that have gone public and listed on the Indonesia Stock Exchange in 20062010. The results showed that leverage has a negative effect on investment decisions, debt maturity has a negative effect on investment decisions, growth opportunities have a positive effect on investment decision, there is no interaction between leverage and growth opportunities as moderation in influencing investment decisions, and growth opportunities can moderate the effect of debt maturity on investment decisions.

$\mathbf{H}_{4}$ : Growth Opportunity has a significant effect on Investment Decisions.

$\mathbf{H}_{5}$ : Liquidity to Equity Ratio, Debt to Asset, Total Asset Turnover, and Growth Opportunity significantly influence Investment Decisions simultaneously. 


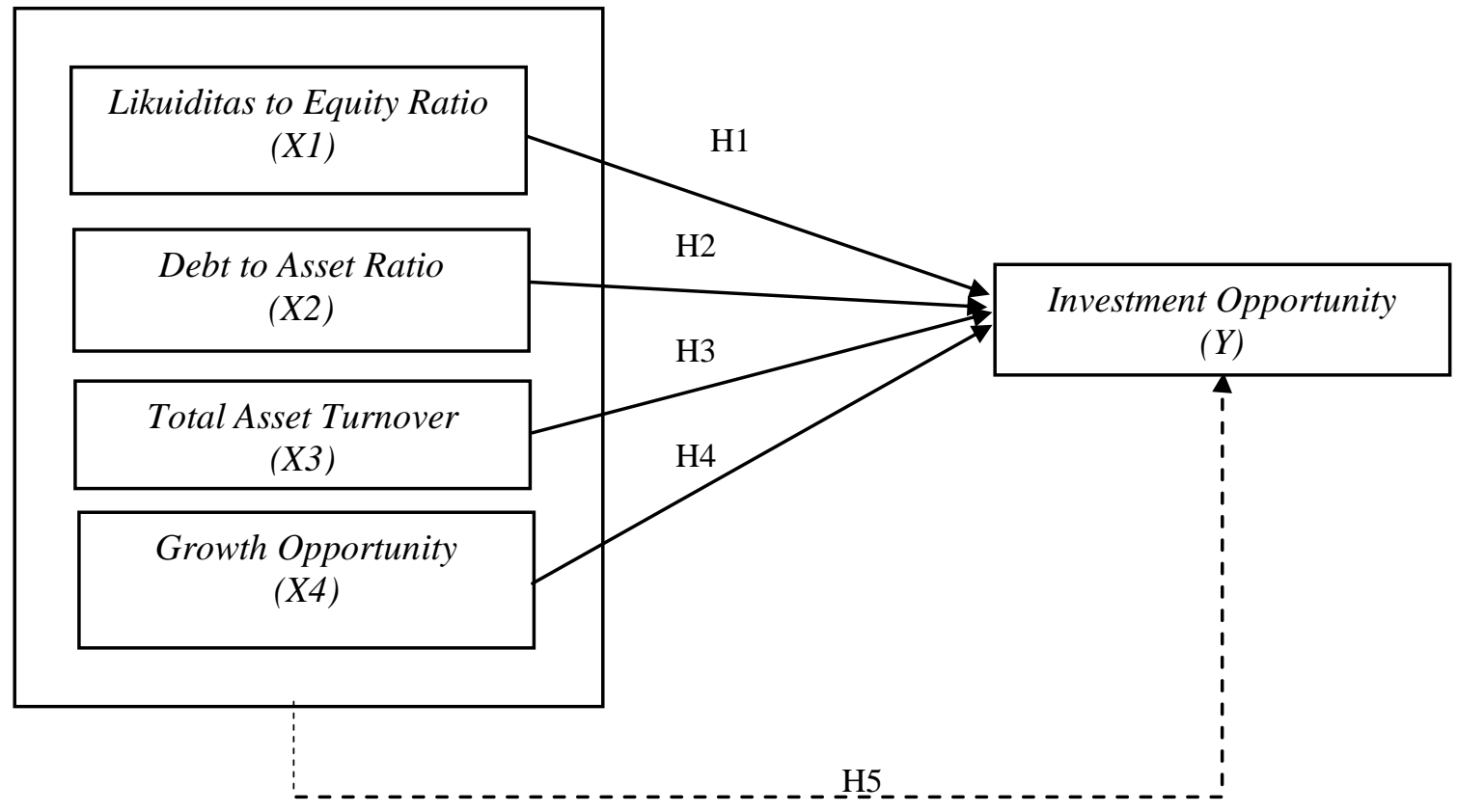

Figure 1. Research Model

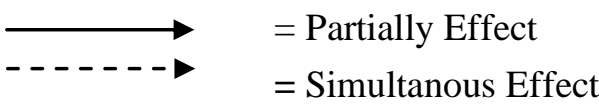

\section{RESEARCH METHODS \\ Population and Sample}

Population is a generalization area consisting of objects/subjects that have certain qualities and characteristics determined by researchers to be studied and draw conclusions (Sugiyono, 2008). The population used in this study was all food and beverage companies listed on the Indonesia Stock Exchange, 18 companies in total. The sampling technique was purposive sampling. According to Sugiyono (2008) purposive sampling is a sampling technique with certain considerations. The criteria are as follows:

1. Food and beverage companies listed on the Indonesia Stock Exchange for 5 consecutive years from 2013 to 2017.

2. Food and beverage companies that publish audited financial statements for 5 consecutive years from 2013 to 2017.

3. Food and beverage companies whose investment decision value for 5 years in a row is above $4 \%$.

From these criteria, there are 6 food and beverage companies that meet the criteria above.

Table 1

Research Sample

\begin{tabular}{lll}
\hline No. & \multicolumn{1}{c}{ Code } & \\
\hline 1. & DLTA & PT. Delta Djakarta, Tbk \\
2. & ICBP & PT. Indofood CBP Sukses Makmur Tbk \\
3. & MYOR & PT. Mayora Indah Tbk \\
4. & ROTI & PT. Nippon Indosari Corporindo Tbk \\
5. & SKBM & PT. Sekar Bumi Tbk \\
6. & SKLT & PT. Sekar Laut Tbk \\
\hline
\end{tabular}




\section{Operational Variable Definition}

\section{Table 2}

\section{Summary of Operational Variable Definition}

\begin{tabular}{|c|c|}
\hline Variable & Variable Definition \\
\hline Liquidity & $\begin{array}{l}\text { Ratio that illustrates the } \\
\text { company's ability to meet its } \\
\text { short-term financial } \\
\text { obligations and helps the } \\
\text { company manage its working } \\
\text { capital. (Sartono, 2010) }\end{array}$ \\
\hline $\begin{array}{l}\text { Debt to } \\
\text { Asset Ratio }\end{array}$ & $\begin{array}{l}\text { The comparison of the ratio of } \\
\text { company debt, which is } \\
\text { obtained from the ratio of total } \\
\text { debt divided by total assets } \\
\text { (Fahmi, 2011) }\end{array}$ \\
\hline $\begin{array}{l}\text { Total Asset } \\
\text { Turnover }\end{array}$ & $\begin{array}{l}\text { Shows capital turnover of total } \\
\text { assets measured by sales } \\
\text { volume in other words how far } \\
\text { the ability of all assets to } \\
\text { create sales. The higher this } \\
\text { ratio, the better (Harahap, } \\
\text { 2009) }\end{array}$ \\
\hline $\begin{array}{l}\text { Growth } \\
\text { Opportunity }\end{array}$ & $\begin{array}{l}\text { The growth of the company's } \\
\text { total assets from year to year } \\
\text { which shows the development } \\
\text { of the company's investment. } \\
\text { This asset growth proxy was } \\
\text { adapted from research } \\
\text { conducted by Song (2005). }\end{array}$ \\
\hline
\end{tabular}

Current Ratio $(C R)=\frac{\text { Current Asset }}{\text { Current Liabilities }}$ Indikator

Indikator

Total Debt to Total Asset $=\frac{\text { Total liabilities }}{\text { Total Asset }} \times 100 \%$

$$
\text { Total Asset Turnover }=\frac{\text { Company Sales }}{\text { Total Asset }}
$$

Growth Opportunity $=\frac{\text { Total Asset }_{(t)}-\text { Total Asset }_{(t-1)}}{\text { Current Liabilities }}$
Investment Determine the amount of Decision assets needed the company (Hartono, 2009) to maximization of holder's wealth shares, which is the maximization of the stock market price company (Keown et al, 2011)
Using Tobin's Q proxy, which is the comparison of the market value of the company's total assets to the book value of the company's assets. (Permanasari, 2010)

Information:

EMV = equity of market value (share price $\mathrm{x}$ number of shares outstanding) $\mathrm{EBV}=$ book value of total assets $\mathrm{D}=$ book value of total debt

$$
\text { Tobin's } Q=\frac{(E M V+D)}{(E B V+D)}
$$


which the Tobins $\mathrm{Q}$ value is $\leq 1$ is indicating the company is not growing and is coded 0 , while the Tobins $Q$ value $>1$ indicates the company is growing and coded 1 .

\section{Data Analysis Technique}

The variables used in this study include liquidity, debt to asset ratio, total asset turnover, growth opportunity, and investment opportunities. This analysis is used to obtain statistical evidence about the influence between variables to be studied. In this stage, each hypothesis will be tested in order to prove its validity. This research was tested using the classical assumption coefficient of determination (R2), normality, goodness of fit, F-test, and hypothesis test (t-test).

\section{RESULTS AND DISCUSSION}

The variables in this study that were used as predictors $\left(\mathrm{X}_{\mathrm{i}}\right)$ or independent are Liquidity to Equity Ratio in which the value $\mathrm{X}_{1}$ is the current ratio value produced by the Food and Beverage company for five years, then followed by the Debt to Asset Ratio variable which the $\mathrm{X}_{2}$ value is the value of debt to total assets produced by the Food and Beverage company for five years, then the Total Asset Turnover variable whereas the value of $\mathrm{X}_{3}$ is the value of the ratio of the company's assets turnover, and Growth Opportunity in which $\mathrm{X}_{4}$ is Tobin's $Q$ value which indicates the company is growing or not. The dependent variable in this study was the Investment Decision in which the value of $\mathrm{Y}$ is the growth value of the total assets produced by the Food and Beverage Company for five years.

\section{Multiple Linear Regression Test}

Hypothesis testing was done by using multiple linear regression with a significant level of $5 \%(\alpha=5 \%)$. The results of multiple linear regression testing are as follows:

Table 3

\section{Multiple Regression Test Result}

\begin{tabular}{lll}
\hline \multirow{2}{*}{ Model } & \multicolumn{2}{c}{ Unstandardized Coefficients } \\
& $\mathrm{B}$ & Std. Error \\
\hline (Constant) & 91.139 & 31.336 \\
CR & -.090 & .034 \\
DAR & -.878 & .460 \\
TATO & -.018 & .061 \\
GO & $-5.646 \mathrm{E}-6$ & .000 \\
\hline
\end{tabular}

Source: Calculated Data

Based on Table 3 above, the multiple linear regression equation as follows:

$$
\mathrm{IC}=91.139-0.090 \mathrm{CR}-0.878 \mathrm{DAR}-0.018 \mathrm{TATO}-0.0000564 \mathrm{GO}
$$

The negative results of all the coefficients above indicate that any increase in liquidity, debt to assets, asset turnover, and growth opportunity is not followed by an increase 
in investment decisions as well. An increase in liquidity, debt to assets, asset turnover, and growth opportunity can cause a decrease in corporate investment decisions, and vice versa.

\section{Partial Test (t-test)}

Partial hypothesis testing was conducted to determine whether the independent variables (liquidity, debt to assets, asset turnover, and growth opportunity) partially have a significant or no influence on investment decisions (ICs) on Food and Beverage companies on the Indonesia Stock Exchange. Results of partial tests conducted using t-tests.

Partial test is the result of testing the level of significance of each coefficient which is the value of the regression coefficient divided by the default error. The regression of a variable has a significant influence on changes in the value of $Y$ if the value of $t>t$ table or significant $<$ significant level (0.05). Based on the test results obtained as follows:

a. The value of liquidity expressed by the current ratio $\left(\mathrm{X}_{1}\right)$ has significance $0.014<$ 0.05 , so it is proven that the variable liquidity to equity ratio has a significant effect on investment decisions. The first hypothesis $\left(\mathrm{H}_{1}\right)$ is supported by this result.

b. The value of debt to asset ratio $\left(\mathrm{X}_{2}\right)$ has a significance of $0.068>0.05$, so it can be said that the variable debt to asset ratio partially does not significantly influence investment decisions. The second hypothesis $\left(\mathrm{H}_{2}\right)$ is not supported by this result.

c. The value of total asset turnover $\left(\mathrm{X}_{3}\right)$ has a significance of $0.771>0.05$, so it can be said that the variable total asset turnover has no significant effect on investment decisions. The third hypothesis $\left(\mathrm{H}_{3}\right)$ is not supported by this result.

d. The value of growth opportunity $\left(\mathrm{X}_{4}\right)$ has a significance of $0.036<0.05$, so it is proven that the growth opportunity variable partially has a significant effect on investment decisions. The fourth hypothesis $\left(\mathrm{H}_{4}\right)$ is supported by this result.

\section{Simultaneous Test (F-Test)}

Hypothesis testing simultaneously between independent variables on the dependent variable was done by using the F-Test. If the significant value $\mathrm{F}<0.05$ and $\mathrm{F}$-count $>\mathrm{F}$-table, then it means the independent variable simultaneously has a significant effect on the dependent variable, but if the significance value F> 0.05 and F-count < F-table then the independent variable simultaneously has no significant effect on the dependent variable.

Based on the results of the F-test, the value of $\operatorname{sig}>\alpha(0.075>0.05)$ with degrees of freedom $(\mathrm{df})=4$ and $\mathrm{df}_{2}=25$, then obtained F-table of 2.76 , which means that F-count $<\mathrm{F}$ table $(2.426<2.76)$. These results indicate that there is no significant simultaneous effect between the variable Liquidity to equity ratio, Debt to Asset Ratio, Total Asset Turnover, and Growth Opportunity on investment decisions. So it can be concluded that hypothesis 5 (H5) is not supported by this result.

\section{Correlation Analysis and Determination}

To find out the closeness of the relationship between the dependent variable (Y) with all independent variables $\left(\mathrm{X}_{1} \mathrm{X}_{2} \mathrm{X}_{3} \mathrm{X}_{4}\right)$ and to see how far the model formed can explain the actual conditions.

The results show the correlation coefficient $(\mathrm{R})$ of 0.529 where the value is at 0.40 0.599 interval (Sugiyono, 2009) which means the level of relationship between variables is moderate. The effect of the independent variable $(\mathrm{X})$ on the dependent variable $(\mathrm{Y})$ is indicated by the coefficient of determination (R-Square). However, according to Santoso 
(2005), if there are more than two independent variables, the influence of the independent variable on the dependent variable is seen by using Adjusted R-Square. Therefore, based on table 4.4 above the Adjusted $\mathrm{R}_{2}$ value is 0.164 or $16.4 \%$. That is, the effect of the variable of liquidity to equity ratio, debt to assets, total asset turnover, and growth opportunity on investment decisions is only $16.4 \%$, the remaining $83.6 \%$ is influenced by other variables outside of this study.

\section{Classic Assumption Test}

The regression model was tested for its effectiveness by using a classic assumption test which included a normality test, a multicollinearity test, a heterokedasticity test, and autocorrelation test.

\section{a. Normality test}

Normality test is carried out to find out whether the residuals under study are normally distributed or not. The results of the normality test are presented in Figure 4.1 below:

\section{Figure 2}

\section{Normality Test Result}

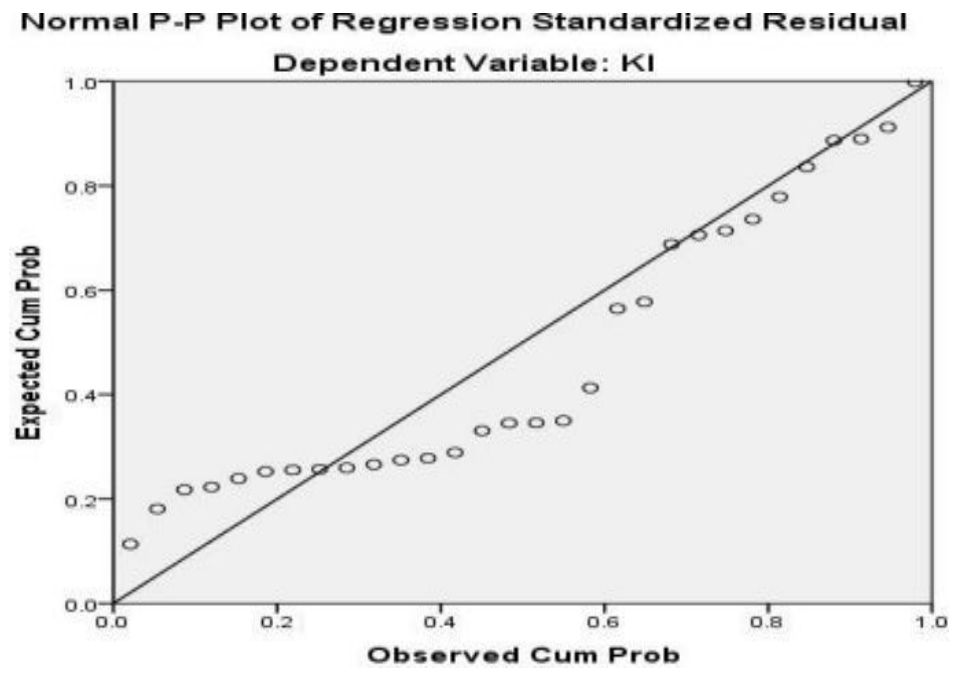

Figure 2 is a Print Out of the Normal P-Plot of Regression Standardized. Based on the diagram above, it can be seen that the presence of points around the line and the scatter plot seems to spread along the diagonal lines. This shows that the model is normally distributed.

\section{b. Multicollinearity Test}

This assumption test is conducted to show whether there is a linear relationship between the independent variables in the regression model and to show whether there is a high degree of colinearity between the independent variables. According to Ghozali (2011), the cut-off value commonly used to indicate multicollinearity is a tolerance value $<0.10$ or equal to a VIF value $>10$. The multicollinearity test results showed the tolerance value of each variable $>0.10$ and the VIF of each variable also showed a value $<10$, so it can be concluded that there was no multicollinearity between the revised independent variables.

\section{c. Autocorrelation Test}

Autocorrelation test can be seen from the value of Durbin Watson. If the Durbin Watson values are in the $\mathrm{dU}$ to $4-\mathrm{dU}$ regions, it can be concluded that the regression model does not contain autocorrelation. 
If $\mathrm{k}=4, \mathrm{n}=30$ and $\alpha=0.05$, then $\mathrm{dL}=1.1426$ and $\mathrm{dU}=1.7386$. Based on table 4.6 above, the value of $d=1,568$, so that $2,432>1.1426((4-d)>d L)$, it can be concluded that there is no autocorrelation problem.

\section{d. Heterokedasticity Test}

This test is used to determine the occurrence of model deviations due to variance of interference between observations. The presence or absence of heterokedasticity can be seen in the following graph:

\section{Figure 3}

\section{Scatterplot of Heterokedasticity}

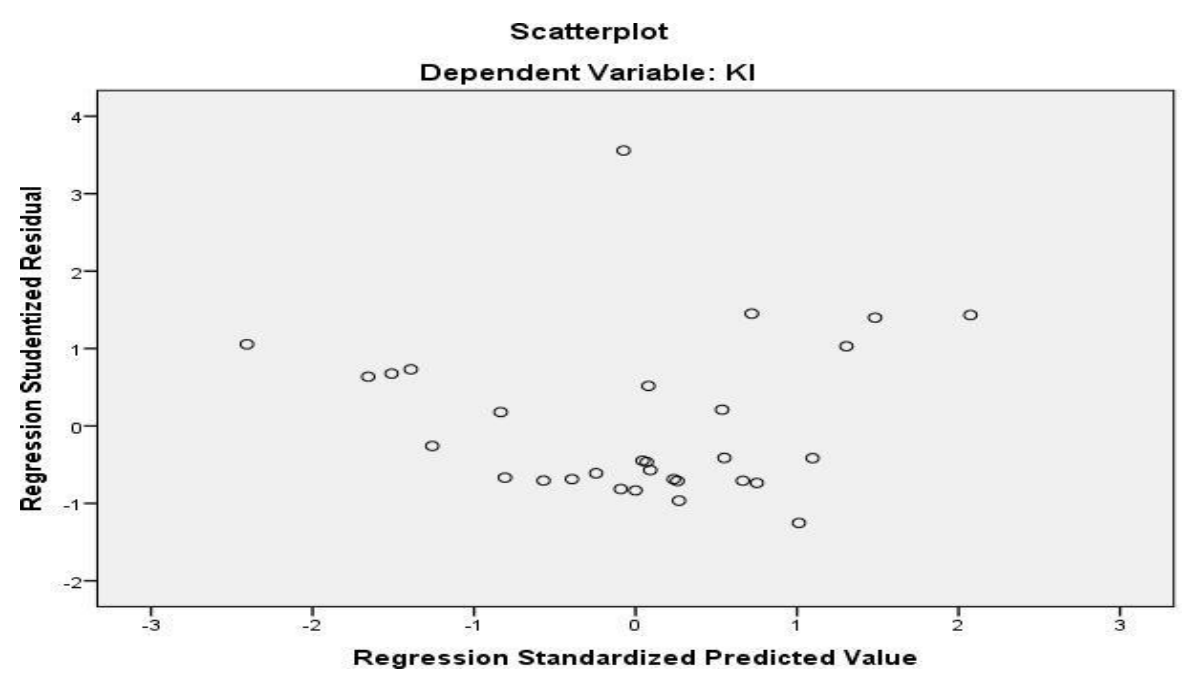

From the graph in Figure 3 above, the pattern of dots does not form a specific pattern and spreads above and below the zero on the $\mathrm{Y}$ axis, it can be concluded that there is no heterokedasticity in the regression model.

\section{Discussion}

The results showed that simultaneous variables Liquidity to equity ratio, Debt to Asset Ratio, Total Asset Turnover, and Growth Opportunity did not significantly influence investment decisions. This is indicated by the magnitude of the Anova value of the F test with sig $>\alpha(0.075>0.05)$ and F-count $<$ F-table $(2.426<2.76)$. This insignificant coefficient value means that if liquidity to equity ratio, Debt to Asset Ratio, Total Asset Turnover, and Growth Opportunity change together, then the change is not followed by changes in investment decisions. This means that when a company decides to make an investment, the company does not decide based on all the variables together (liquidity variables, the ratio of debt and assets of the company, asset turnover, and company growth), but may only focus on a number of variables in accordance with company needs.

The results of the analysis of the correlation coefficient and determination based on table 4.4 shows that the value of the correlation coefficient $(\mathrm{R})$ of 0.529 , which means the relationship between variables, is moderate. Whereas the coefficient of determination for the independent variable is more than 2, which is indicated by the value of Adjusted R2 showing the value of 0.164 or $16.4 \%$. That is, the effect of the variable liquidity to equity ratio, debt to 
assets, total asset turnover, and growth opportunity on investment decisions is only $16.4 \%$, the remaining $83.6 \%$ is influenced by other variables outside this study.

The partial research results for each independent variable are explained as follows:

\section{Liquidity to Equity Ratio}

Based on the results of the study, liquidity has a significant effect on investment decisions, as indicated by the significant value of $0.014<0.05$. The liquidity regression coefficient of 0.090 indicates that there is a negative relationship (opposite direction) between liquidity and investment decisions, where if liquidity increases, investment decisions will decrease. This finding rejects the results of the study of Ramadhan, et al (2017) which states that the Current Ratio has a direct relationship and does not have a significant effect on investment decisions

The negative relationship between the independent and dependent variables is due to the fact that $40 \%$ of the sample food and beverage company experienced a decrease in investment that was not followed by a decrease in liquidity. The company's liquidity ratio shows that companies prefer to use existing assets to pay off obligations rather than to invest.

\section{Debt to Asset Ratio}

The test results show that the debt to asset ratio $\left(\mathrm{X}_{2}\right)$ has a significance of $0.068>0.05$, so it can be said that the variable debt to asset ratio has no significant effect on investment decisions. This means the ups and downs of the debt to asset ratio only have a very small impact on investment decisions. Debt to asset ratio (DAR) also has a regression coefficient of -0.878 , which means there is a negative relationship (opposite direction) between DAR and investment decisions. These findings are in line with research Soumaya (2012) which states that the debt has a negative effect on theinvestment-cash flow sensitivity.

If the DAR increases, investment decisions will decrease, and vice versa. These results indicate that the higher DAR value means that the higher the company's debt ratio. The high debt ratio of the company will certainly reduce the interest of companies to invest and focus more on the use of existing assets on paying off debts (liabilities), both short-term debt and long-term debt.

\section{Total Asset Turnover (TATO)}

Partial test results ( $\mathrm{t}$-test) indicate that the value of total asset turnover (TATO) has a significance of $0.771>0.05$, so it can be said that the variable total asset turnover has no significant effect on investment decisions. This means that sooner or later a company's asset turnover will not have much impact on the investment decisions made. The results of the study are in line with Martha's research (2010) which revealed that total assets turnover is not significant effect on fixed asset investment

TATO regression coefficient value is -0.018 , which means there is a negative relationship (opposite direction) between TATO with investment decisions. The higher the TATO is, the lower the investment decision will be, and vice versa. Fast asset turnover shows the ability of all assets to make sales also fast. Companies that have high TATO to generate sales will not necessarily have a good investment development, because the sales obtained are not all in the form of cash, but some are in the form of receivables. Therefore, if the company already has enough debt, the investment capability of the company will decrease even though the TATO increases. 


\section{Growth Opportunity (GO)}

Based on the test results obtained a significance value of growth opportunity (GO) of $0.036<$ 0.05 , so it is proven that the growth opportunity variable partially has a significant effect on investment decisions. The regression coefficient value of GO is -0.0000564 , which shows that there is a negative relationship (opposite direction) between the GO variable with investment decisions. This finding is contrary to the results of research from Sandiar (2017) who found that growth opportunity has a positive effect on investment decisions.

That is, the higher the company's opportunity to grow (growth opportunity), the investment decisions will actually be smaller. This can occur because companies that have high growth opportunity have a high tendency to also use the assets they have to fund the company's operations compared to making additional investments. Conversely, if the company has a low growth opportunity, the company will tend to try to increase the opportunities that exist by investing in long-term debt.

\section{CONCLUSION}

Based on the results explained above, it can be concluded that simultaneously Liquidity to equity ratio, Debt to Asset Ratio, Total Asset Turnover, and Growth Opportunity variables have no significant effect on investment decisions. This means changes in all the independent variables together do not have a large impact on investment decisions. Therefore, it was concluded that $\mathrm{H}_{5}$ was not supported. Based on the results of t-tests that have been conducted, partially, the variables that have a significant effect on investment decisions are only liquidity and growth opportunity $\left(\mathrm{H}_{1}\right.$ and $\mathrm{H}_{4}$ are supported), whereas the debt to asset ratio (DAR) and total asset turnover (TATO) variables indicate that partially no significant effect on investment decisions $\left(\mathrm{H}_{2}\right.$ and $\mathrm{H}_{3}$ are not supported). The regression coefficient values of all independent variables show a negative value which means there is an inverse relationship between the variable Liquidity to equity ratio, Debt to Asset Ratio, Total Asset Turnover, and Growth Opportunity to investment decisions. This means that if the value of Liquidity to equity ratio, Debt to Asset Ratio, Total Asset Turnover, and Growth Opportunity is getting higher then investment decisions will actually decrease, and vice versa. The research has implications on preventive efforts for food and beverage companies to further optimize the use of their assets so that they can be more effective in making decisions related to decisions for operational funding, paying off obligations, or even investment and expansion. Food and beverage companies are also expected to be able to improve their financial performance and be wiser in using debt. A high debt ratio must be followed by a high repayment capability so that it can survive and have a great opportunity to continue to grow. This study has limitations in terms of small sample sizes so it is hoped that further researchers can improve the quality of research using large sample sizes and longer years.

\section{REFERENCE}

Fahmi, I. 2011. Manajemen Investasi: Teori dan Soal Jawaban. Salemba Empat. Jakarta. Fahmi, Irham dan Yovi Lavianti Hadi. 2011. Teori Portofolio dan Analisis Investasi. Cetakan kedua.Bandung: Alfabeta. 
Ghozali, I. 2013. Update PLS Reg Aplikasi Multivariate dengan Program IBM SPSS resi. Edisi Ketujuh. Badan Penerbit Universitas Diponegoro. Semarang.

Ghozali, Imam. 2011. Aplikasi Analisis Multivariate Dengan Program SPSS . Semarang: Badan Penerbit Universitas Diponegoro.

Halim, Abdul. 2005. Analisis Investasi. Jakarta:salemba Empat.

Harap, Sofyan Syafri. 2010. Analisis Kritis Atas Laporan Keuangan. Edisi Satu. Jakarta: Raja Grafindo Persada.

Hartono, Jogiyanto. 2009. Teori Portofolio dan Analisis Investasi. Edisi Keenam. Yogyakarta: BPFE-Yogyakarta.

Hartono dan Wahyuni. 2017. Analisis Faktor-faktor Keputusan Inivestasi pada Perusahaan Property dan Real Estate. Jurnal Ilmu dan Riset Manajemen, Vol. 6, Nomor 6, Juni 2017.

Hartono, E. F., 2017. Analisis Faktor-Faktor Keputusan Investasi Pada Perusahaan Property dan Real Estate. Jurnal Ilmu dan Riset Manajemen, Vol.6, Nomor 6, Juni 2017.

Hanafi, Mamduh M. 2004. Manajemen Keuangan. Yogyakarta: BPFE.

Hidayat, Riskin. 2010. Keputusan Investasi dan Financial Constraints. Studi Empiris pada Bursa Efek Indonesia. Buletin Ekonomi Moneter dan Perbankan.

Kasmir. 2010. Analisis Laporan Keuangan. Cetakan Ketiga. Jakarta: Raja Grafindo Persada.

Keown, Arthur J dan John D Martin et al. 2011. Manajemen Keuangan: Prinsip dan Penerapan. Terjemahan oleh Marcus Prihminto Widodo. Jilid 1. Edisi Kesepuluh. Jakarta: PT. Indeks.

Martha, Sri.’Pengaruh Kinerja Keuangan terhadap Investasi Aktiva Tetap pada Perusahaan Telekomunikasi Bidang Industri Barang Konsumen yang Terdaftar di BEI". Jurnal. Jakarta. 2010.

Ramadhan, Febi Ary. Brady R., dan Tika T.2017. The Effect Of Return On Assets, Earning Per Share, Dividend Per Share, Debt To Assets Ratio And Current Ratio On Shareholder Investment Decisions (Study On Telecommunication Companies Listed On Indonesia Stock Exchange Period 2010-2015). e-Proceeding of Management : Vol.4, No.3 Desember 2017:2148

Sandiar, Loecita. 2017. Growth Opportunity Dalam Memoderasi Pengaruh Leverage Dan Debt Maturity Terhadap Keputusan Investasi. Journal of Applied Business and Economics, Vol. 3 No. 4 (Jun 2017) 196-206

Santoso,Singgih. 2005. Menggunakan SPSS untuk Statistik Parametrik. Jakarta.PT. Elek Media Komputindo.

Saragih. 2008. Faktor-Faktor yang Mempengaruhi Keputusan Investasi Pada Perusahaan Barang Konsumsi di Bursa Efek Indonesia, Universitas Sumatera Utara, Medan.

Sartono, Agus. 2010. Manajeman Keuangan Teori Dan Aplikasi. Edisi 4, BPFE: Yogyakarta.

Soumaya, Hechmi. 2012. The effect of debt, firm size and liquidity on investment -cash flow sensitivity. International Journal of Accounting and Financial Reporting ISSN 2162-3082 2012, Vol. 2, No. 2

Sugiyono. 2008. Metode Penelitian Bisnis. Bandung: Alfabeta.

Sutrisno. 2012. Manajemen keuangan: Teori, Konsep, dan Aplikasi. Edisi Pertama. Yogyakarta: Ekonisia. 
Syamsuddin, Lukman. 2009. Manajemen Keuangan Perusahaan Konsep Aplikasi dalam: Perencanaan, Pengawasan dan Pengambilan Keputusan. Edisi Baru. Jakarta: Raja Grafindo Persada. 